\title{
The Effect of Process Oriented Guided Inquiry Learning (POGIL) Model on Students' Concepts Mastery
}

\section{Ni Wayan Erisca Pradiyanasari ${ }^{1)}$, Ni Nyoman Sri Putu Verawati ${ }^{\left.{ }^{*}\right)}$, Aris Doyan ${ }^{1)}$}

${ }^{1)}$ Department of Physics Education, Mataram University, Indonesia

\author{
*Corresponding Author Email: veyra@unram.ac.id
}

\section{Article History}

Received: March 2020

Accepted: April 2020

Published: June 2020

Key Words

POGIL model;

concept mastery

How to cite this article?

\begin{abstract}
This study aims to determine the effect of the Process Oriented Guided Inquiry Learning (POGIL) model on the students' concept mastery in SMAN 6 Mataram, subject matter of harmonious vibration. This study is a quasiexperimental research with a pretest-posttest control group design. The population was all students of class X MIA at SMAN 6 Mataram in the 2018/2019 academic year totaling 172 students, with purposive sampling technique obtained by class X MIA 1 as an experimental class and class X MIA 3 as a control class. The concept mastery test instrument uses multiple choice questions totaling 25 items. The concept mastery data obtained were analyzed using t-test with a significance level $(\alpha)$ of $5 \%$. Hypothesis test results indicate that the $t$-count is greater than $t$-table that is 2.482 is greater than 2.020, so that $\mathrm{H}_{0}$ is rejected and $\mathrm{H}_{\mathrm{a}}$ is accepted. Thus, there is an effect of the Process Oriented Guided Inquiry Learning (POGIL) model on students' concept mastery.
\end{abstract}

Pradiyanasari, N., Verawati, N., \& Doyan, A. (2020). The Effect of Process Oriented Guided Inquiry Learning (POGIL) Model on Students' Concepts Mastery. Lensa: Jurnal Kependidikan Fisika, 8(1), 25-30. doi:https://doi.org/10.33394/j-1kf.v8i1.2776

\section{INTRODUCTION}

Physics is a part of science that is essentially a collection of knowledge, ways of thinking, and inquiry. Physics is not only a collection of facts, concepts, or principles, but also a process of discovery and prospects for further development in applying it in everyday life. According to Suranti et al (2016), physics is a lot of lessons in the form of equations and some abstract concepts so it is difficult to understand. The abstract concept of physics often becomes an obstacle for teachers in delivering material to students, so students are not optimal in understanding the concepts explained by the teacher. This certainly has an impact on students 'learning interest in receiving physics lessons which causes low mastery of students' concepts to solve a problem. Umam et al (2012) states that mastery of concepts becomes very important for students because this is an indicator that students have fully understood what has been taught, not just memorizing, so that later mastery of this concept can help students in solving physical problems which is not only in learning at school, but also in everyday life. Silaban (2014) defines concept mastery as an effort that students must do in recording and transferring back a number of information from a particular subject matter that can be used in solving problems, analyzing, interpreting on a particular event. Through the ability to master the concepts of good physics will help students in solving problems faced.

Initial observations were made through interviews with physics subject teachers and students at SMAN 6 Mataram. Based on observations, information is obtained that physics is often considered a difficult subject, too many formulas, and boring. The physics 
learning process that has taken place so far is still dominated by conventional learning, where at the time the learning takes place it is still centered only on the teacher (teaching center), relying on the use of lecture methods so that students just sit, listen, and record whatever is conveyed by the teacher without participate in expressing their opinions. Therefore, students have a tendency to memorize formulas rather than mastering concepts.

Efforts to overcome these learning problems, it takes the teacher's skills in choosing learning models that are varied and centered on students so that students can take an active role in learning. The use of the right model can train students in terms of knowledge so that students can more easily understand and improve the mastery of students' physics concepts, in addition students can benefit from the learning process that has been done. Through the discovery of concepts guided students will be able to understand the concepts learned in more depth, so in this case the researchers try to use the POGIL learning model (Sanggara et al., 2018). According to Rustam et al (2017) the application of the POGIL learning model has a positive influence on the understanding of science concepts, in this case the POGIL learning model emphasizes the concept formation independently by students with teacher guidance, thus giving a deep impression on the concepts learned.

The Process Oriented Guided Inquiry Learning (POGIL) model can improve students' understanding and mastery of concepts because in the POGIL learning model emphasizes a learning process that directs students to find answers themselves to questions or problems, thereby helping them to gain a deeper understanding. According to Widyaningsih (2012) states in the POGIL class, students work in groups (called team learning) aimed at mastering concepts. This learning model is part of the inquiry training teaching model that implements by bringing students together with a slightly confusing problem, raising questions, conducting experiments, building and testing ideas. Meanwhile, according to Widyaningrum et al (2016), the application of the POGIL learning model will provide a more pleasant learning atmosphere because in the learning steps students will explore to find the concepts of the material being taught.

Zawadzki (2010) provides an explanation that the teacher-centered learning model is no longer sufficient to meet the educational goals and needs of students in a professional manner. The POGIL model is student-centered learning that works in groups (called team learning) aimed at mastering concepts not rote, students are able to develop skills, think high-level, metacognition, communication, teamwork, management, and assessment. Mastery of the concept of physics as one aspect in measuring student learning outcomes is very important to be improved. According to Hamdani (2012) the concept is the thought of a person or group of people expressed in the definition, law and theory. In line with this statement, Doyan \& Sukmantara (2014) states that the concept is anything that takes the form of new notions that can arise as a result of thought, including definitions, special characteristics, nature, essence or content and so on.

\section{METHOD}

This study is a quasi-experimental study with a pretest-posttest control group design. The research design is as in Table 1 . Before the teaching and learning activities take place, both classes are given a pre-test to find out the mastery of the students' initial concepts. After that, the control class is given treatment by applying conventional learning, while in the experimental class treatment is given by applying the Process Oriented Guided Inquiry Learning (POGIL) model. At the end of the research activity, in both classes the students were given a post-test to find out the increase in students' mastery of the concept after being given such treatment. 
Table 1. Experimental design (Setyosari, 2013)

\begin{tabular}{cccc}
\hline Class & Pre-test & Treatment & Post-test \\
\hline Experiment & $\mathrm{O}_{1}$ & $\mathrm{X}$ & $\mathrm{O}_{2}$ \\
Control & $\mathrm{O}_{3}$ & - & $\mathrm{O}_{4}$ \\
\hline
\end{tabular}

The population was all students of class X MIA at SMAN 6 Mataram in the 2018/2019 academic year totaling 172 students, with purposive sampling technique obtained by class X MIA 1 as an experimental class and class X MIA 3 as a control class. The concept mastery test instrument uses multiple choice questions totaling 25 items. The concept mastery test is carried out various kinds of tests which include validity test, reliability test, difficulty level test and different power test. Data analysis prerequisite test uses homogeneity test and data normality test. Data analysis test is done by t test.

\section{RESULTS AND DISCUSSION}

This study aims to determine whether there is an effect of the Process Oriented Guided Inquiry Learning (POGIL) model on students' concept mastery. The results showed the average value of the pre-test mastery of the concept of the experimental class was 42.3 and the control class was 41.4. It can be seen that the initial ability of the students of both classes is still low, this is because the two groups of samples have not yet received harmonious vibration material. The post-test values of the two classes, namely the experimental class and the control class, obtained an average value of mastery of concepts of 81.3 and 71.8. When compared, the average value of the experimental class post-test was higher than the control class even though both classes both experienced an increase after being treated. Data on the average score of the initial test and the final test of mastery of concepts can be seen in Table 2 and Table 3.

Table 2. Pretest average score of concept mastery

\begin{tabular}{ccccc}
\hline Class & $\mathrm{N}$ & Highest Val. & Lowest Val. & Average \\
\hline Experiment & 33 & 56 & 28 & 42,3 \\
Control & 31 & 56 & 24 & 41,4 \\
\hline
\end{tabular}

Tabel 3. Posttest average score of concept mastery

\begin{tabular}{ccccc}
\hline Class & $\mathrm{N}$ & Highest Val. & Lowest Val. & Average \\
\hline Experiment & 33 & 92 & 52 & 81,3 \\
Control & 31 & 88 & 48 & 71,8 \\
\hline
\end{tabular}

The results of the hypothesis test using the t-test showed that the Process Oriented Guided Inquiry Learning (POGIL) model had an influence on the experimental class, because the value of $t$-count $>t$-table was $2.482>2.020$, so $\mathrm{H}_{0}$ was rejected and $\mathrm{H}_{\mathrm{a}}$ was accepted. It means that there is an effect of the Process Oriented Guided Inquiry Learning (POGIL) model on students' concept mastery of the harmonic vibration material. T-test results can be seen in Table 4 .

Table 4 . The result of t-test

\begin{tabular}{cccc}
\hline Class & $\mathrm{N}$ & t-count & t-table \\
\hline Experiment & 33 & 2,482 & 2,020 \\
Control & 31 & & 20 \\
\hline
\end{tabular}

This effect is caused by the application of the POGIL model which directs students to more easily master the concept of harmonious vibration because it is taught through experimental activities, teamwork or groups in solving problems regarding recovery style 
and the period and frequency of pendulum swings and spring vibrations given by the teacher, so that memory learners can last longer. This result is supported by research conducted by Yudiasminiati (2009), which shows that the learning outcomes of students who are treated with the POGIL model are higher than the learning outcomes of students who learn with conventional models, this is because in the POGIL learning process of students active in finding answers to problems given so that students' memories can last longer, besides that students can also use the concepts they have to solve similar things in their daily lives.

Another influence of the POGIL learning model on the mastery of the concept of harmonic vibrations of students is because the phases in the POGIL learning model can make students more directed and think actively in the learning process. In the first phase, which asks, the teacher presents problems related to the recovery style and the period and frequency of the pendulum swing and spring vibration, then the students study the problem in groups so that students can identify the problem well and can exchange ideas with group friends to add knowledge. Not only studying the problems that have been given, students are also able to improve the ability to form hypotheses of a problem. This is in line with research by Ningsih et al (2012) which states that the POGIL model can improve critical thinking skills and improve aspects of hypothesizing, analyzing and concluding. The second phase is observing, trying and the third phase is reasoning, the teacher gives full guidance in finding concepts, building concepts and monitoring data collection activities and students conduct experiments and collect observational data. By experimenting students experience firsthand the process that they learn so that they are truly focused on what is being done or learned. In the fourth phase, forming a network of students applying the concepts of harmonic vibration obtained to solve problems related to the new situation in the form of exercises that are solved by discussing with group members. The final phase of the POGIL learning model is the conclusion and conclusion can make students evaluate the solutions that have been used in solving problems given because in this phase students present the results of group work and the teacher guides, provides reinforcement and provides an assessment so that students can evaluate solutions to problems well and after that make conclusions from the results of learning. The exchange of information, the use of group members' ideas and cooperation will have a positive impact on all members of the group who are either less capable or group members who are more capable. In addition, students are trained to respect the opinions of friends with a variety of solutions from each group that will lead students to discover their own concepts being studied.

In the application of the POGIL learning model, at the end of each learning teacher requires students to read the learning material that will be studied at the next meeting. Thus students who have studied the material in advance will be more ready to follow the learning process and have an initial concept that will facilitate the finding of concepts, so mastery of the concepts in the material of harmonious vibrations learned is stronger. This opinion is supported by research Rahayu \& Pamelasari (2015) which states that the strengths of the POGIL learning model are seen from the readiness of students in the learning process, because students prepare themselves first about the material to be studied, therefore students have readiness in the form of knowledge and understanding of the initial concept of the material to be learned.

The control class taught using conventional learning makes the teacher as the information center or facilitator so that the students are less active in asking questions in the learning and discussion process, besides that the students are also less brave to express their opinions in class. In the control class during the discussion process not all students took an active role in doing the exercises where only a few students worked and other students just waited for the results. This resulted in the mastery of the concept of 
harmonious vibrations of students in the control class after being given lower treatment than the experimental class. Similar results were shown by research conducted by Sari et al (2017) and Furoidah et al (2017) that the direct instruction learning model resulted in students tending to listen, taking notes which caused students to feel bored in learning so that students' physics learning outcomes were low. Unlike the stages or phases in the Process Oriented Guided Inquiry Learning (POGIL) model, where students conduct experiments and all members play an active role in groups.

\section{CONSLUSSION}

Based on the results of this study, it can be concluded that there is an influence of the Process Oriented Guided Inquiry Learning (POGIL) model on the students' concept mastery in harmonic vibration material.

\section{RECOMMENDATION}

Some suggestions proposed by researchers to optimize the use of the POGIL model, are (1) learning time is planned and allocated effectively so that all stages of learning take place properly, (2) it is necessary to organize students as well as possible in each stage of POGIL learning model so that the process learning can run effectively, (3) other researchers who want to conduct similar research, are expected to check and prepare practicum tools in school laboratories for the material to be taught in advance as best as possible so that learning can proceed according to the objectives to be achieved.

\section{REFERENCES}

Doyan, A., \& Sukmantara, I. K. Y. (2014). Pengembangan web intranet fisika untuk meningkatkan penguasaan konsep dan kemampuan pemecahan masalah siswa SMK. Jurnal Pendidikan Fisika Indonesia, 10(2), 117-127.

Furoidah, A. Z., Indrawati, I., \& Subki, S. (2017). Implementasi model discovery learning disertai lembar kerja siswa dalam pembelajaran fisika siswa di SMA. Jurnal Pembelajaran Fisika, 6(3), 285-291.

Hamdani, D., Kurniati, E., \& Sakti, I. (2012). Pengaruh model pembelajaran generatif dengan menggunakan alat peraga terhadap pemahaman konsep cahaya kelas VIII di SMP Negeri 7 Kota Bengkulu. Jurnal Exacta, 10(1), 79-88.

Ningsih, S. M., Bambang S. \& Sopyan, A. (2012). Implementasi model pembelajaran process oriented guided inquiry learning (POGIL) untuk meningkatkan kemampuan berpikir kritis peserta didik. Unnes Physics Education Journal, 1(2), 4452.

Rahayu, D. P., \& Pamelasari, S. D. (2015). Pengaruh model pembelajaran process oriented guided inquiry learning terhadap kemampuan berpikir kritis peserta didik pada materi perubahan benda. USEJ. 4(3), 936-944.

Rustam, Ramdani, A., \& Setijani, P. (2017). Pengaruh model pembelajaran process oriented guided inquiry learning (POGIL) terhadap pemahaman konsep IPA, keterampilan proses sains dan kemampuan berpikir kritis siswa SMP Negeri 3 Pringgabaya Lombok Timur. Jurnal Penelitian Pendidikan IPA (JPPIPA), 3(2), 33-41.

Sari, E. R., Pasaribu, M., \& Sahena, S. (2017). Pengaruh model discovery learning terhadap hasil belajar fisika pada pokok bahasan kalor di SMP Negeri 2 Pamona Timur. Jurnal Inovasi dan Pembelajaran Fisika, 4(2), 119-126.

Setyosari, P. (2013). Metode penelitian pendidikan dan pengembangan (edisi keempat). Malang: Pranada Media Group. 
Silaban, B. (2014). Hubungan antara penguasaan konsep fisika dan kreativitas dengan kemampuan memecahkan masalah pada materi pokok listrik statis. Jurnal Penelitian Bidang Pendidikan, 20(1), 65-75.

Suranti, N. M. Y., Gunawan., \& Sahidu, H. (2016). Pengaruh model project based learning berbantuan media virtual terhadap penguasaan konsep peserta didik pada materi alat-alat optik. Jurnal Pendidikan Fisika dan Teknologi, 2(2), 73-79.

Umam, A. N., Maharta, N., \& Rosidin, U. (2012). Analisis penguasaan konsep fisika siswa dengan kemampuan berpikir konkrit dan berpikir formal. Jumal Pembelajaran Fisika, 1(1), 1-12.

Widyaningrum, P. S., Pujiastuti, E., \& Wijayanti, K. (2016). Keefektifan pembelajaran model pogil berbantuan kartu masalah terhadap kemampuan pemecahan masalah dan karakter bangsa siswa kelas VIII. UNNES Journal of Mathematics Education, 5(3), 207-216.

Widyaningsih, S. Y., Haryono, \& Saputra, S. (2012). Model MFI dan POGIL ditinjau dari aktivitas belajar dan kreativitas siswa terhadap prestasi belajar. JURNAL INKUIRI, 1(3), 266-275.

Zawadzki, R. 2010. Is process oriented guided inquiry learning (POGIL) suitable as a teaching method in Thailand's higher education. Asian Journal on Education and Learning, 1(2), 66-74 